\title{
Aberrant septin 11 is associated with sporadic frontotemporal lobar degeneration
}

\author{
Yair M Gozal ${ }^{1,4}$, Nicholas T Seyfried ${ }^{2,3,4}$, Marla Gearing ${ }^{1,4}$, Jonathan D Glass ${ }^{1,4}$, Craig J Heilman ${ }^{1,4}$, Joanne Wuu', \\ Duc M Duong 2,3,4, Dongmei Cheng ${ }^{2,3,4}$, Qiangwei Xia ${ }^{2,4}$, Howard D Rees ${ }^{1,4}$, Jason J Fritz ${ }^{1,4}$, Deborah S Cooper ${ }^{1,4}$, \\ Junmin Peng ${ }^{2,3,4 \dagger}$, Allan I Levey ${ }^{1,4+}$ and James J Lah L $^{1,4^{*}+}$
}

\begin{abstract}
Background: Detergent-insoluble protein accumulation and aggregation in the brain is one of the pathological hallmarks of neurodegenerative diseases. Here, we describe the identification of septin 11 (SEPT11), an enriched component of detergent-resistant fractions in frontotemporal lobar degeneration with ubiquitin-immunoreactive inclusions (FTLD-U), using large-scale unbiased proteomics approaches.

Results: We developed and applied orthogonal quantitative proteomic strategies for the unbiased identification of disease-associated proteins in FTLD-U. Using these approaches, we proteomically profiled detergent-insoluble protein extracts prepared from frontal cortex of FTLD-U cases, unaffected controls, or neurologic controls (i.e. Alzheimer's disease; AD). Among the proteins altered specifically in FTLD-U, we identified TAR DNA binding protein-43 (TDP-43), a known component of ubiquitinated inclusions. Moreover, we identified additional proteins enriched in detergent-resistant fractions in FTLD-U, and characterized one of them, SEPT11, in detail. Using independent highly sensitive targeted proteomics approaches, we confirmed the enrichment of SEPT11 in FTLD-U extracts. We further showed that SEPT11 is proteolytically cleaved into N-terminal fragments and, in addition to its prominent glial localization in normal brain, accumulates in thread-like pathology in affected cortex of FTLD-U patients.
\end{abstract}

Conclusions: The proteomic discovery of insoluble SEPT11 accumulation in FTLD-U, along with novel pathological associations, highlights a role for this cytoskeleton-associated protein in the pathogenesis of this complex disorder.

Keywords: Neurodegeneration, dementia, proteomics, mass spectrometry, ubiquitin, aggregates

\section{Background}

Frontotemporal lobar degeneration (FTLD) encompasses a heterogeneous group of sporadic and familial diseases associated with circumscribed degeneration of the prefrontal and anterior temporal lobes. As the third most common neurodegenerative cause of dementia behind Alzheimer's disease (AD) and Lewy body dementia, FTLD accounts for 5\% of dementia cases irrespective of age [1]. Pathologically, FTLD is equally heterogeneous, and may present as a tauopathy, or more commonly, with tau-negative, ubiquitin-immunoreactive neurites and inclusions [2]. In these cases, termed FTLD-

\footnotetext{
* Correspondence: jlah@emory.edu

+ Contributed equally

'Department of Neurology, Emory University School of Medicine, Atlanta, GA 30322. USA

Full list of author information is available at the end of the article
}

ubiquitin (FTLD-U), histopathology is primarily observed within the small layer II neurons of the frontal and temporal cortices, as well as in granule cells of the dentate gyrus of the hippocampus [3].

In recent years, significant progress has been made in understanding the genetic and neuropathologic basis of FTLD-U. In 2006, mutations in the progranulin gene $(G R N)$ were identified as the cause of chromosome 17linked FTLD-U $[4,5]$. This discovery was followed by the identification of TAR DNA-binding protein 43 (TDP43), the first major non-ubiquitin protein component of pathological inclusions in familial and sporadic FTLD-U [6]. Although in normal neurons TDP-43 is a nuclear RNA-binding protein, in pathologic conditions TDP-43 redistributes from the nucleus to the cytoplasm where it is aggregated, phosphorylated, ubiquitinated, and
C Biomed Central

() 2011 Gozal et al; licensee BioMed Central Ltd. This is an Open Access article distributed under the terms of the Creative Commons Attribution License (http://creativecommons.org/licenses/by/2.0), which permits unrestricted use, distribution, and reproduction in any medium, provided the original work is properly cited. 
proteolytically cleaved into C-terminal fragments [6]. Notably, TDP-43 is also localized in the intracytoplasmic ubiquitinated inclusions of sporadic amyotrophic lateral sclerosis (ALS), a motor neuron disease often associated with FTLD-U $[3,6]$, and mutations in TDP-43 have been linked to ALS [7-10].

The molecular pathways underlying TDP-43 aggregation and toxicity have not yet been fully elucidated. Fragmentation of TDP-43, possibly by caspase-dependent cleavage [11], and its subsequent cytoplasmic sequestration have been posited as critical factors in promoting cellular toxicity $[12,13]$. However, several reports have questioned the specificity of the association between TDP-43 and FTLD-U/ALS after TDP-43 immunoreactive aggregates were found in a range of neurodegenerative disorders, including AD and Parkinson's disease (PD) [14,15]. In addition, extensive histopathological characterization of FTLD-U cases with TDP-43 specific antibodies has revealed at least four pathologic FTLD-U subtypes that differ in aggregate distribution, density, and morphology, suggesting that they may not share a common molecular basis $[16,17]$. Finally, cases caused by mutations in the $C H M P 2 B$ gene, as well as sporadic cases with FUS-immunoreactive inclusions, feature ubiquitin-positive inclusions that lack TDP-43 immunoreactivity $[18,19]$. Taken together, these findings suggest that other, as yet unknown, proteins may contribute in the pathogenesis of this complex disorder. Thus, in the current study we applied quantitative proteomics methodologies to identify molecular substrates and pathways involved in FTLD-U pathogenesis. Application of these strategies in performing shotgun proteomic analyses of FTLD-U samples resulted in the identification of SEPT11, a novel FTLD-U-associated protein that is enriched in detergent-insoluble fractions and accumulates in the brain of FTLD-U cases.

\section{Results and Discussion}

\section{Discovery of altered proteins in FTLD-U by LC-MS/MS}

To identify differentially expressed proteins in FTLD-U, which like TDP-43 are enriched in detergent-insoluble brain fractions, we examined post-mortem samples using two independent shotgun quantitative proteomic approaches (Figure 1a-b). In the first strategy, frontal cortex homogenates from 10 cases each of FTLD-U, $\mathrm{AD}$, and control (Table 1) were pooled by diagnosis and serially extracted with buffers of increasing stringency. To allow estimation of the variances associated with sample preparation and analysis, the FTLD-U pooled homogenates were divided into two identical samples and processed in parallel as technical replicates. The resulting four detergent-insoluble, urea-soluble fractions were first separated by SDS-PAGE (Additional File 1a), excised in 5 bands from the gel, trypsin digested, and analyzed via liquid chromatography coupled with tandem mass spectrometry (LC-MS/MS) on a high resolution mass spectrometer. For each of the 512 identified proteins, a quantitative protein comparison based on the extracted ion current (XIC) of individual peptides was performed, and abundance ratios calculated (e.g. FTLD$\mathrm{U} / \mathrm{Control}$ ). To statistically evaluate and filter the quantitative data, the abundance ratios from all pair-wise comparisons were logarithmically transformed and the resulting histogram of all values was fitted to a Gaussian distribution (Additional Files 2 and 3). In all, 50 proteins were found to be significantly altered in FTLD-U when compared to control and $\mathrm{AD}$ extracts.

To reduce the variances in the proteomics analysis, we performed an independent study using a separate MS strategy based on the use of culture-derived isotopic tags (CDIT), and cross-referenced the findings with the first label-free approach [20]. In this second approach, whole cell lysate from isotopically-labeled HEK 293 cells was mixed equally with urea-soluble fractions prepared from pools of 4 FTLD-U or 4 control cases (Table 1 marked by asterisk). The heavy-labeled peptides from the cell lysate are chemically identical to their unlabeled counterparts in each urea fraction, and can therefore serve as internal standards for the measurement of protein abundance across samples [21]. The urea/HEK 293 lysate mixtures were subsequently separated by SDSPAGE (Additional File 1b) and also excised in 5 bands for LC-MS/MS analysis. Using the heavy-labeled internal standard as a reference between FTLD-U and control samples, abundance ratios were calculated, converted into $\log _{2}$ values, plotted as a histogram of all proteins, and fitted to a Gaussian distribution (Additional File 4). Of the 1304 proteins identified in this approach, 194 were found to be altered in FTLD-U compared with control. Among the 10 proteins significantly altered in both proteomic discovery sets (Table 2), we identified Septin 11 (SEPT11), a 429 amino acid cytoskeletal GTPase thought to play a role in filament formation [22]. SEPT11 was consistently enriched $\sim 4$-fold in FTLD-U compared to control across all molecular weight regions in both proteomics experiments. In the label-free approach, we identified 3 SEPT11 peptides (Additional File 5), and quantification revealed a total signal to noise ratio (SN) of 19.9 in both FTLD-U replicates compared with 4.6 in the control sample. Similarly, we identified the same 3 peptides in the CDIT strategy, as well as an additional peptide, with total SN of 134.4 in FTLD-U and 43.4 in control. As expected, TDP-43 was also increased in FTLD-U, albeit more modestly than SEPT11, showing $\sim 1.8$-fold and $\sim 1.3$-fold enrichment in the label-free and CDIT quantitative proteomics approaches, respectively. The specificity of our proteomics strategy was further validated by comparison with 
A

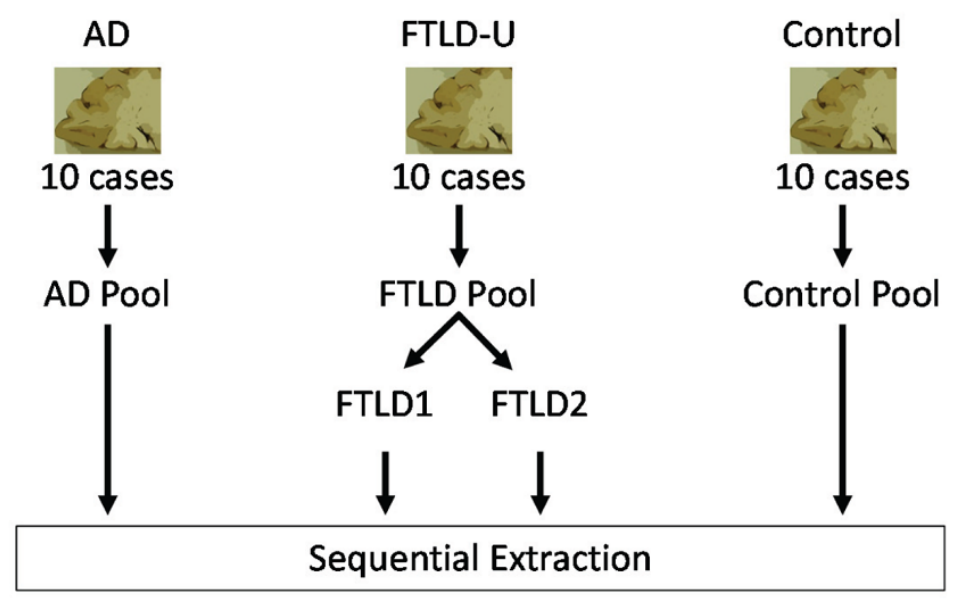

B Culture Derived Isotopic Tags Quantitative Proteomics Heavy

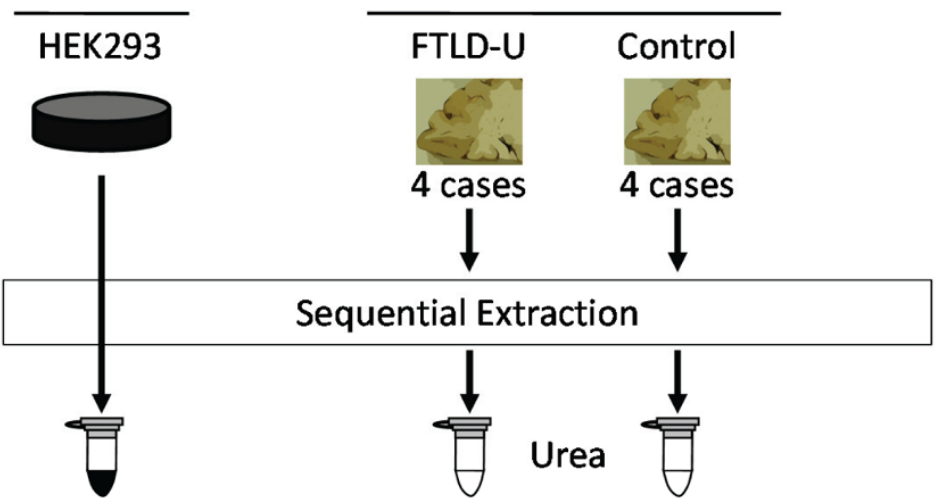

Mix cell lysate 1:1

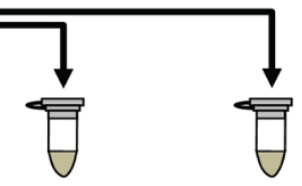

Light + Heavy

C

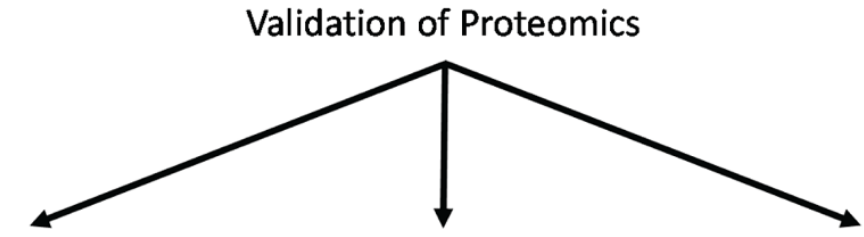

Targeted Proteomics Western Blot Immunohistochemistry

Figure 1 Diagram of experimental workflow. (a) Sample preparation for label-free quantitative proteomics (Discovery Phase A). Ten cases each of AD, FTLD-U, and Control were pooled by diagnosis and sequentially extracted. Urea samples were then analyzed by shotgun LC-MS/MS. (b) Sample preparation for quantitative proteomics based on culture derived isotopic tags (Discovery Phase B). Four cases each of FTLD-U and control were pooled by diagnosis and sequentially extracted. Urea fractions for each diagnosis were mixed (1:1) with HEK293 lysate labeled with heavy stable isotopes of arginine and lysine. The heavy labeled peptides served as internal standards following analysis by LC-MS/MS. (c) Validation of identification of Septin 11 enrichment in FTLD-U using three independent methods. 
Table 1 Detailed Demographics of Cases Selected for Proteomics

\begin{tabular}{|c|c|c|c|c|c|c|c|}
\hline Diagnosis & Case \# & & ${ }^{1} \mathrm{PMI}$ (hr) & Age at Death & Duration & ApoE Status & ${ }^{2}$ Race/Sex \\
\hline & 1 & & 4 & 55 & 6 & $E 3 / 3$ & W/M \\
\hline & 2 & & 4.5 & 55 & 3 & $E 3 / 4$ & W/F \\
\hline & 3 & & 20 & 57 & 7 & $E 3 / 4$ & $B / F$ \\
\hline & 4 & & 11.5 & 62 & 10 & $E 3 / 4$ & W/M \\
\hline \multirow[t]{6}{*}{$A D$} & 5 & & 4.5 & 64 & 12 & $E 3 / 4$ & W/F \\
\hline & 6 & & 5.5 & 69 & 21 & $\mathrm{E} 4 / 4$ & W/F \\
\hline & 7 & & 15 & 71 & 2.5 & $E 3 / 4$ & W/M \\
\hline & 8 & & 17 & 71 & 8 & $E 3 / 4$ & W/M \\
\hline & 9 & & 21 & 76 & 12 & $E 2 / 3$ & W/F \\
\hline & 10 & & 12 & 81 & 12 & $E 3 / 4$ & W/F \\
\hline \multirow[t]{5}{*}{$n=10$} & AVG & & 11.5 & 66.1 & 9.4 & & \\
\hline & 1 & & 3 & 52 & & $E 3 / 4$ & W/F \\
\hline & 2 & & 10 & 57 & & $E 3 / 3$ & W/M \\
\hline & 3 & $3 *$ & 8 & 60 & & $E 3 / 4$ & $B / F$ \\
\hline & 4 & & 12 & 61 & & $E 3 / 4$ & $\mathrm{~B} / \mathrm{M}$ \\
\hline \multirow[t]{6}{*}{ Control } & 5 & & 12 & 65 & NA & $E 3 / 3$ & W/M \\
\hline & 6 & & 6 & 65 & & $E 3 / 3$ & W/F \\
\hline & 7 & $*$ & 11 & 68 & & $E 3 / 3$ & W/F \\
\hline & 8 & $*$ & 6 & 69 & & $E 3 / 3$ & W/M \\
\hline & 9 & & 7 & 74 & & $E 3 / 3$ & W/F \\
\hline & 10 & $*$ & 6 & 75 & & $E 3 / 3$ & W/F \\
\hline \multirow[t]{5}{*}{$n=10$} & AVG & & 8.1 & 64.6 & NA & & \\
\hline & 1 & & 3 & 41 & 9 & $E 3 / 3$ & W/M \\
\hline & 2 & & 17.5 & 61 & 5 & $E 3 / 3$ & W/M \\
\hline & 3 & $*$ & 11.5 & 62 & 10 & $E 3 / 3$ & $A / F$ \\
\hline & 4 & $*$ & 17 & 63 & 7.5 & $E 3 / 3$ & W/M \\
\hline \multirow[t]{6}{*}{ FTLD-U } & 5 & & 6 & 64 & 8 & $E 3 / 4$ & W/F \\
\hline & 6 & * & NA & 69 & 1 & $E 3 / 3$ & W/F \\
\hline & 7 & & NA & 69 & 1 & $E 3 / 3$ & W/F \\
\hline & 8 & & 18 & 71 & 9 & $E 3 / 3$ & W/F \\
\hline & 9 & & 17 & 74 & 16 & $E 3 / 4$ & W/M \\
\hline & 10 & $*$ & 7 & 83 & 4 & $E 3 / 3$ & W/F \\
\hline$n=10$ & AVG & & 12.1 & 65.7 & 7.1 & & \\
\hline
\end{tabular}

${ }^{1}$ Post-mortem interval ${ }^{2}$ White, Black, Asian, Female, Male ${ }^{3}$ Cases marked with asterisk were selected for pooling in CDIT proteomics.

Table 2 Proteins specifically altered in FTLD-U urea fractions using two independent proteomics strategies.

\begin{tabular}{|c|c|c|c|c|}
\hline \multirow[t]{2}{*}{ Protein } & \multirow[t]{2}{*}{$\begin{array}{c}\text { GeneBank }^{\mathrm{TM}} \\
\text { Accession Number }\end{array}$} & \multicolumn{2}{|c|}{$\begin{array}{l}\text { Label-Free Approach } \\
\text { mean } \log _{2} \text { Ratio }\end{array}$} & \multirow{2}{*}{$\begin{array}{l}\text { CDIT Approach } \\
\log _{2} \text { Ratio } \\
\text { FTLD-U/Control }\end{array}$} \\
\hline & & FTLD-U/Control & FTLD-U/AD & \\
\hline Septin 11 & NP_060713.1 & 2.0 & 2.4 & 1.8 \\
\hline Excitatory Amino Acid Transporter 2 & NP_004162.2 & 2.0 & 1.5 & 4.2 \\
\hline Glial Fibrillary Acidic Protein & NP_002046.1 & 1.9 & 1.3 & 2.2 \\
\hline Alpha Catenin & NP_001894.2 & 1.3 & 1.3 & 3.9 \\
\hline Aquaporin 4 & NP_004019.1 & 1.1 & 0.9 & 10.1 \\
\hline Protein Phosphatase 2 & NP_055040.2 & 1.0 & 1.2 & 1.8 \\
\hline Transketolase & NP_001055.1 & 0.9 & 1.1 & 2.2 \\
\hline 2,4-Dienoyl CoA Reductase 2 & NP_065715.1 & -1.1 & -0.9 & -3.2 \\
\hline Rho GTPase Activating Protein 1 & NP_004299.1 & -1.5 & -1.0 & -1.6 \\
\hline Synaptosomal-Associated Protein 25 & NP_003072.2 & -1.5 & -1.0 & -4.9 \\
\hline
\end{tabular}


AD cases, as SEPT11 was not correspondingly increased in insoluble material from AD frontal cortex. This finding indicates that the enrichment of SEPT11 in FTLD-U is not a non-specific association with protein aggregates, and that it is distinct from proteins associated with neurofibrillary tangles and senile plaques. Moreover, known AD-associated proteins, including $\beta$-amyloid, tau, and apolipoprotein $E$, were all enriched in insoluble fractions in AD cases but not in FTLD-U [23].

\section{Validation of SEPT11 enrichment in FTLD-U}

Septins are a highly conserved family of filamentous proteins first identified in yeast as a group of cell division cycle regulatory genes [24]. The 14 mammalian septins identified to date share a central characteristic P-loop GTP-binding domain flanked $\mathrm{N}$ - and C-termini which vary in length and amino acid composition [25]. Based on their amino acid sequence homology and their capacity to interchange with other septins in heteromeric complexes that underlie filament assembly, mammalian septins can be further classified into four subgroups. SEPT11 belongs to the septin 6 (SEPT6) subfamily, which along with other subgroup members (septins 8 and 10) may provide for redundancy in the formation of the septin $2 / 6 / 7$ and $7 / 9 b / 11$ filamentous complexes $[22,26]$. SEPT11 and SEPT6 share $85 \%$ homology, and both are expressed in the CNS [27-29]. Therefore, to confirm the proteomic identification of SEPT11 in FTLD-U urea fractions, we first used a targeted mass spectrometry approach to map unique SEPT11 peptides in SEPT11-overexpressing HEK 293 cells. We subsequently selected 5 of these unique peptides and validated their presence in urea fractions prepared from 4 pooled FTLD-U cases (Additional File 6). Finally, we re-quantified SEPT11 at its expected molecular weight (Gel piece 3; 40-60 kDa) in the pooled urea samples containing the heavy-labeled SEPT11 HEK 293 cell lysate. Specifically, we monitored multiple high intensity product ions, which serve as surrogates for measurement of peptide intensities, from two unique peptides corresponding to amino acids 66-79 and 400418 (Figure 2). SEPT11 was enriched 2.1-fold $( \pm 0.2)$ in FTLD-U compared to control in this gel band (Table 3). In contrast, concurrent examination of $3 \beta$-actin peptides revealed a slight reduction of this reference protein in FTLD-U samples $(0.7 \pm 0.1)$.

The 2-fold discrepancy in SEPT11 enrichment obtained via the shotgun proteomics analyses and the highly sensitive and specific targeted proteomics strategy, suggests that SEPT11 may also be enriched in additional molecular weight regions. Stratification of the data obtained in the proteomic approach using CDIT by molecular weight demonstrated widespread distribution of SEPT11 peptides throughout the entire mass range, with spectra identified in every gel band. Quantitation using XIC and the heavy-labeled internal standard showed a 1.6 to 2fold enrichment of SEPT11 at the 40-60 kDa range, with higher and lower molecular weight regions accounting for the remainder of the $\sim 4$-fold change in these samples. To confirm the changes observed by mass spectrometry, we performed immunoblots on FTLD-U and control urea fractions using a rabbit polyclonal antibody raised to a peptide (amino acids 1-15) at the extreme N-terminus of SEPT11 (Figure 3). In addition to the expected band at $49 \mathrm{kDa}$ corresponding to the full length protein, we detected 3 specific SEPT11immunoreactive bands at $\sim 45 \mathrm{kDa}, \sim 37 \mathrm{kDa}$, and $\sim 28$ $\mathrm{kDa}$ in FTLD-U urea fractions that were absent or reduced in control extracts (Figure 3c) and in the corresponding detergent-soluble fractions (Additional File 7). Quantification of immunoblot band intensities showed a modest but significant 1.8-fold enrichment $(p=0.006)$ of the full-length SEPT11 band in frontal cortex urea fractions from 7 FTLD-U and 9 control cases (Figure $3 \mathrm{~d}$ ), supporting the quantitative mass spectrometric measurements at this molecular weight. Moreover, SEPT11 lower $M_{r}$ fragments were 3.1-fold enriched in these FTLD-U cases compared to controls $(p<0.001)$. The proteolytic cleavage of SEPT11 is consistent with that observed for other pathologic aggregating proteins, including TDP-43 and tau, where polymerization, posttranslational modification, and degradation underlie protein insolubility $[6,30]$.

To examine if the SEPT11 biochemical insolubility reflects an altered distribution in FTLD-U, we performed immunohistochemical analysis using our specific N-terminal polyclonal antibody. SEPT11 immunoreactivity was localized with astrocytic cell bodies and processes in frontal cortex of FTLD-U and control cases (Figure 4a-b). Moreover, we observed neuropil immunoreactivity consistent with the localization of SEPT11 along dendrites and in post-synaptic membranes as has been previously described [31]. Analysis revealed no SEPT11 overlap with TDP-43 and ubiquitin-positive neuronal inclusions. However, in a subset of FTLD-U cases, we identified numerous fibrillar thread-like structures which did not associate with glial processes or nuclei (Figure 4c-e). These SEPT11-immunoreactive features localized primarily in superficial cortical layers (layers 2-3), and appeared irregular in shape, length, and thickness. Antibody specificity was confirmed using peptide competition studies, resulting in the complete loss of immunoreactivity in glia, neuropil, and pathologic threads. In contrast, we were unable to preadsorb a thread-like pathology seen with a separate commercially available SEPT11 antibody.

To determine whether SEPT11 threads correspond to a disease-specific signature, we examined and scored 
A
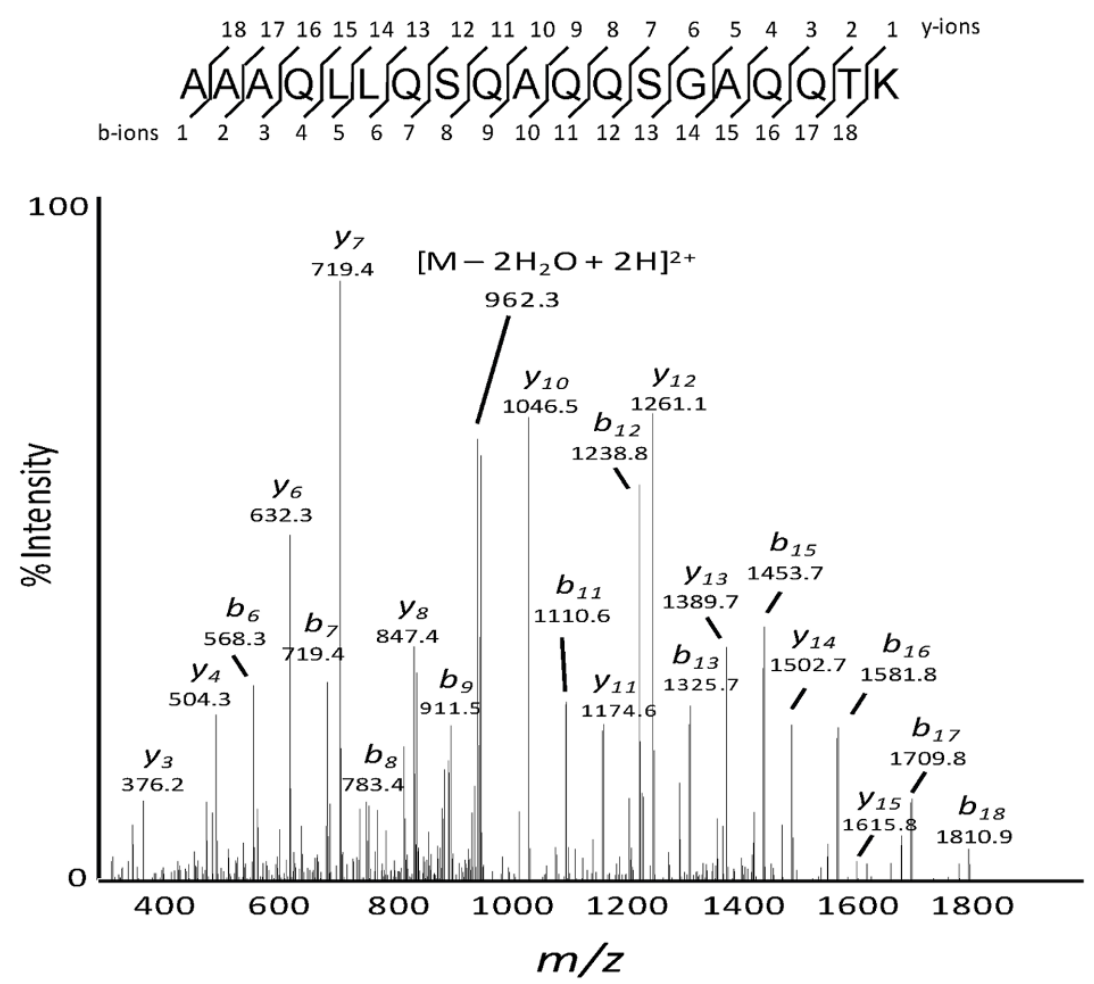

B
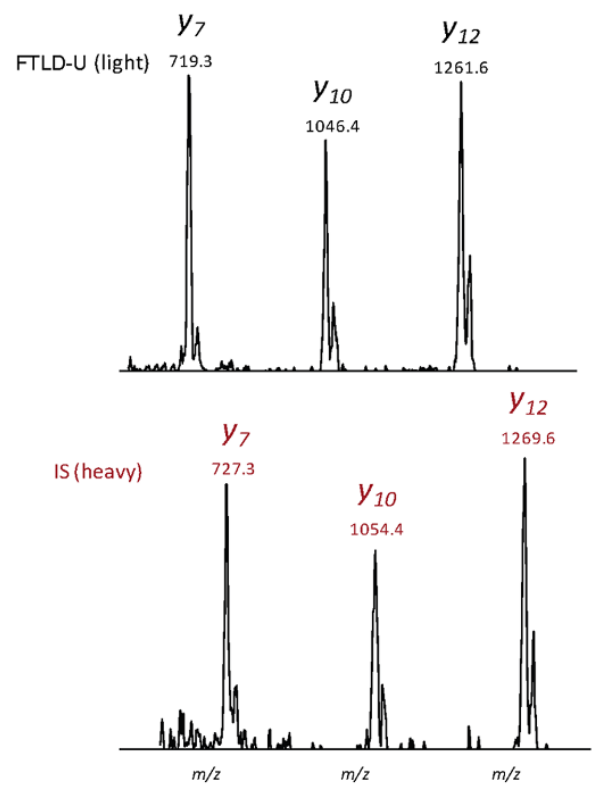

C

FTLD-U Control

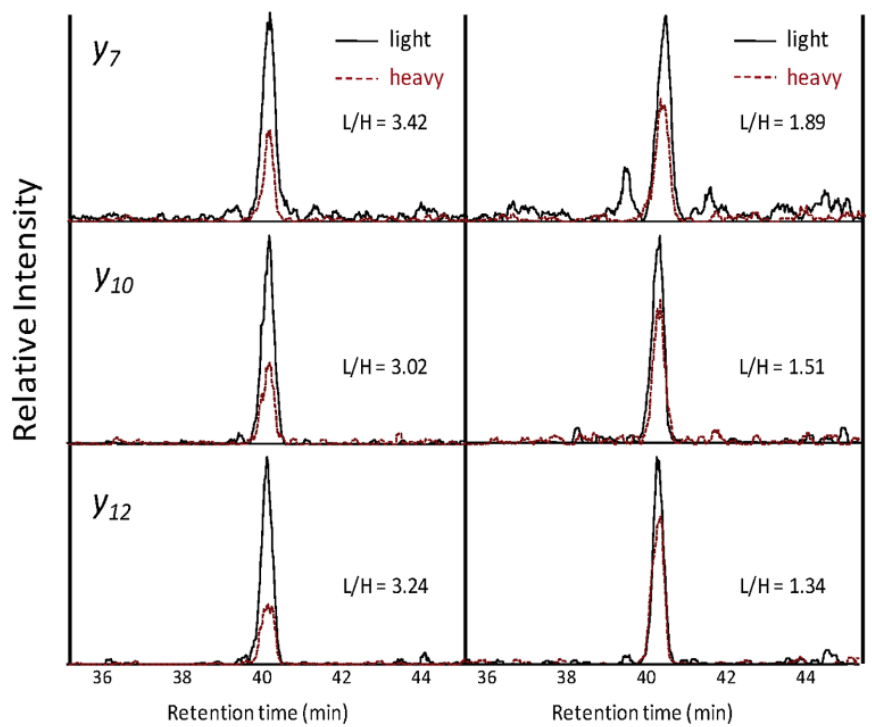

Figure 2 Targeted proteomics to quantify SEPT11 enrichment in urea fractions. (a) MS/MS scan of the precursor ion $(\mathrm{m} / \mathrm{z} 979.0)$ corresponding to a unique SEPT11 peptide (amino acids 400-418). (b) MS/MS product ions selected for quantitation in light (top) and heavy (bottom) peptide forms. (c) Extracted ion chromatogram of targeted spectra for each of the product ions in (b). The spiked heavy- (red) and endogenous light (black) peptides have identical retention times and are overlaid. For each product ion, enrichment is calculated as a ratio of light to heavy signal of the area under each curve. 
Table 3 Targeted MS conditions for Septin11 peptides in gel band corresponding to 40-60 kDa.

\begin{tabular}{|c|c|c|c|c|c|c|c|c|c|c|c|}
\hline \multirow{2}{*}{ Protein Name } & \multirow{2}{*}{ Peptide Sequences } & \multicolumn{2}{|c|}{${ }^{1}$ Precursor lons $(\mathrm{m} / \mathrm{z})$} & \multicolumn{3}{|c|}{${ }^{5}$ Product lons $(m / z)$} & \multicolumn{2}{|c|}{${ }^{6} \mathrm{AUC}$ (FTLD-U) } & \multicolumn{2}{|c|}{ AUC (Control) } & \multirow[t]{2}{*}{ FTLD-U/Contro } \\
\hline & & Native $\left({ }^{2} L\right)$ & ${ }^{3}$ IS $\left({ }^{4} \mathrm{H}\right)$ & Name & Native (L) & IS (H) & (L) & (H) & (L) & (H) & \\
\hline \multirow[t]{3}{*}{ Septin11 } & FESDPATHNEPGVR & 778.4 & 783.4 & & & & & & & & \\
\hline & & & & y2-10 & 539.4 & 544.4 & 2420 & 1034 & 1776 & 1531 & 2.0 \\
\hline & & & & $y 1-10$ & 1077.3 & 1087.3 & 5428 & 1176 & 3548 & 1797 & 2.3 \\
\hline \multirow[t]{7}{*}{ Septin11 } & AAAQLLQSQAQQSGAQQTK & 979.0 & 983.0 & & & & & & & & \\
\hline & & & & y1-7 & 719.3 & 727.3 & 2700 & 790 & 1747 & 921 & 1.8 \\
\hline & & & & $y 1-10$ & 1046.4 & 1054.4 & 2242 & 743 & 1559 & 1030 & 2.0 \\
\hline & & & & $y 1-12$ & 1261.6 & 1269.6 & 3476 & 1074 & 1790 & 1334 & 2.4 \\
\hline & & & & & & & & & & & $2.1 \pm 0.2$ \\
\hline & & \multicolumn{2}{|c|}{ Precursor lons $(m / z)$} & & & & \multicolumn{2}{|c|}{${ }^{7} \mathrm{XIC}$ (FTLD-U) } & \multicolumn{2}{|c|}{ XIC (Control) } & \\
\hline & & Native (L) & IS (H) & & & & (L) & (H) & (L) & (H) & \\
\hline$\beta$-actin & AGFAGDDAPR & 488.73 & 493.74 & & & & 3208 & 916 & 3799 & 717 & 0.7 \\
\hline$\beta$-actin & GYSFTTTAER & 566.77 & 571.78 & & & & 2651 & 740 & 4109 & 896 & 0.8 \\
\hline \multirow[t]{2}{*}{$\beta$-actin } & SYELPDGQVITIGNER & 895.96 & 900.96 & & & & 2474 & 704 & 2806 & 584 & 0.7 \\
\hline & & & & & & & & & & & $0.7 \pm 0.1$ \\
\hline
\end{tabular}

${ }^{1}$ The $\mathrm{m} / \mathrm{z}$ values of native and labeled peptides ${ }^{2}$ Light ${ }^{3}$ Internal Standard ${ }^{4}$ Heavy ${ }^{5}$ The name and $\mathrm{m} / \mathrm{z}$ values of monitored product ions (e.g. y1-7, the singlycharged y7 ion) ${ }^{6}$ Area under the curve ${ }^{7}$ Extracted ion chromatogram.

this characteristic staining in a series of FTLD-U, ALS, neurologic disease control (AD, PD, and tauopathies), and normal control cases in a blinded fashion using a semi-quantitative 4-tiered rating scale (Additional File 8). SEPT11 threads were markedly enriched in FTLD-U, with $56 \%$ of cases $(9 / 16)$ scored as having positive or very positive (score $\geq 2$ ) staining of threads (Figure $4 \mathrm{f}$ ). In comparison, only $18 \%(7 / 39 ; p=0.008)$ of neurologic controls and $22 \%(4 / 18 ; p=0.076)$ of normal controls were scored in this range. Moreover, when FTLD-U and ALS, the two disease groups associated with TDP-43, were examined together and compared to the TDP-43 negative neurologic controls (AD, PD, and tauopathies), the difference in SEPT11 pathology was even stronger $(p<0.001)$. This provided additional support for shared pathogenic mechanisms in FTLD-U and ALS. Since their presence is highly specific to FTLD-U and ALS, SEPT11-immunoreactive threads may reflect pathologic accumulations of the insoluble full-length or fragmented protein identified in urea fractions.

\section{Conclusions}

Perturbed expression of septins, a family of cytoskeletal GTP-binding proteins, has been extensively associated with neurodegeneration. Notably, SEPT1, SEPT2, and SEPT4 have been shown to co-localize with neurofibrillary tangles and dystrophic neurites in AD [32]. In PD, SEPT4 co-localizes with $\alpha$-synuclein in Lewy bodies [33], and SEPT5 has been shown to be a target for parkin-mediated ubiquitination [34]. In this study, we have shown that SEPT11 is biochemically altered and accumulates in FTLD-U. Although the specific functions of
SEPT11 in the brain are not well defined, SEPT11 is thought to form multi-septin complexes that assemble into filaments and function as scaffolds for cytoskeletalbinding proteins [35]. Supporting this potential role, SEPT11 has been shown to colocalize with microtubules and stress fibers in multiple epithelial cell lines [36]. Thus, it is plausible that changes in SEPT11 solubility could disrupt cytoskeletal function and result in cellular toxicity, a mechanism already established for tau-based proteopathies in other neurodegenerative disorders [37]. In fact, SEPT11 insolubility and toxicity may be related to the presence of lower $M_{r}$ fragments in FTLD-U urea fractions identified by immunoblotting (Figure 3 ). This would parallel findings in a highly homologous protein, SEPT6, in which N-terminal fragments containing the variable region and GTP-binding domain have been reported to be insoluble [38]. As is seen with multiple disease proteins, including TDP-43, tau, $\alpha$-synuclein, and $A \beta[39,40]$, proteolytic cleavage of SEPT11 may result in protein misfolding, aggregation, and cytotoxicity. Finally, truncation of the SEPT11 C-terminus would also impact the coiled-coil domain of the protein, a region critical for septin-septin interactions as well as for binding to non-septin partners $[31,38]$.

Our characterization of SEPT11 in FTLD-U establishes a powerful approach to large-scale identification of disease-associated proteins in neurodegenerative conditions through analysis of the detergent-insoluble proteome. SEPT11 immunoreactive threads are a novel neuropathological feature of a subgroup of FTLD-U cases, but accumulation of insoluble SEPT11 aggregates is not a universal feature of all FTLD-U cases. Our 


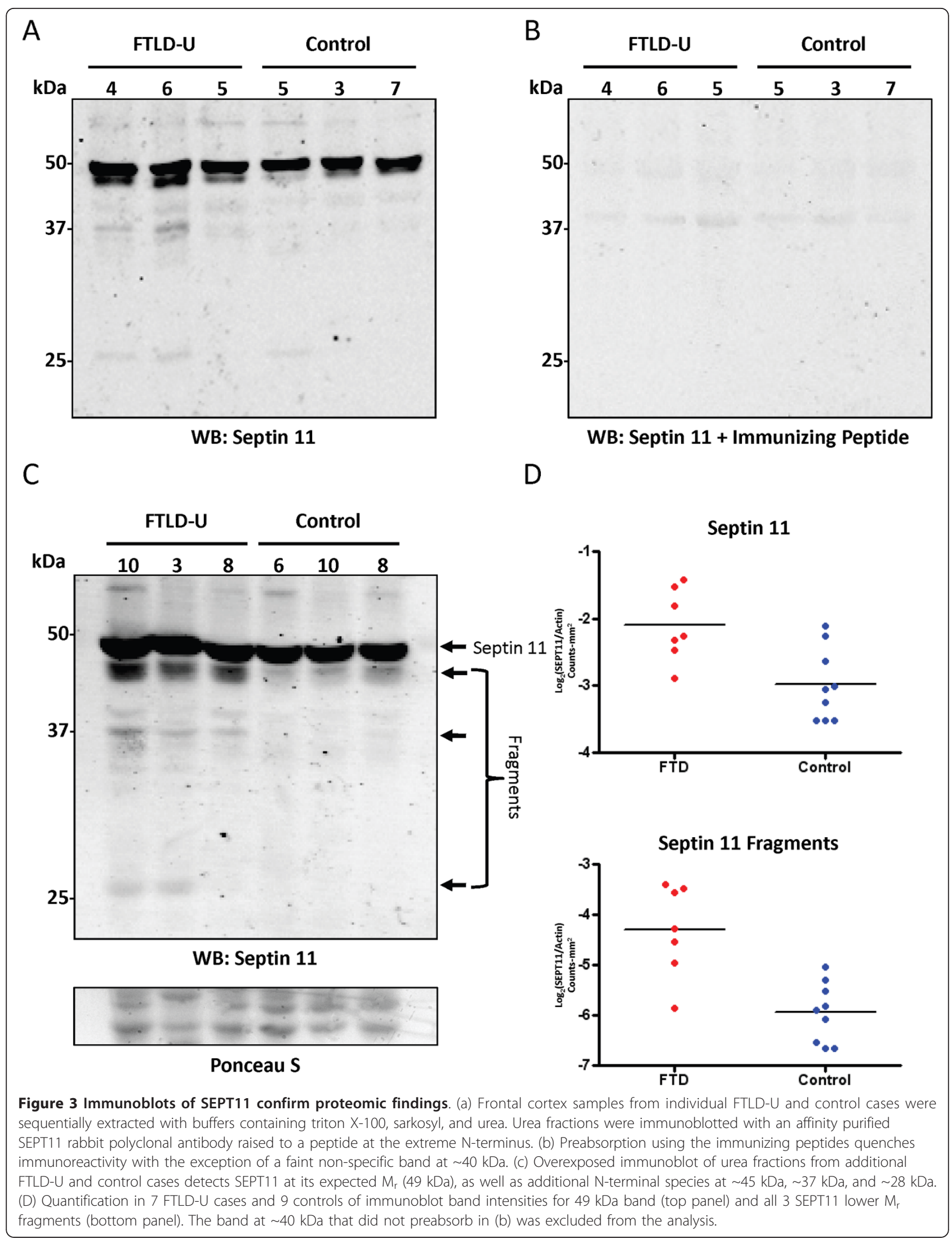




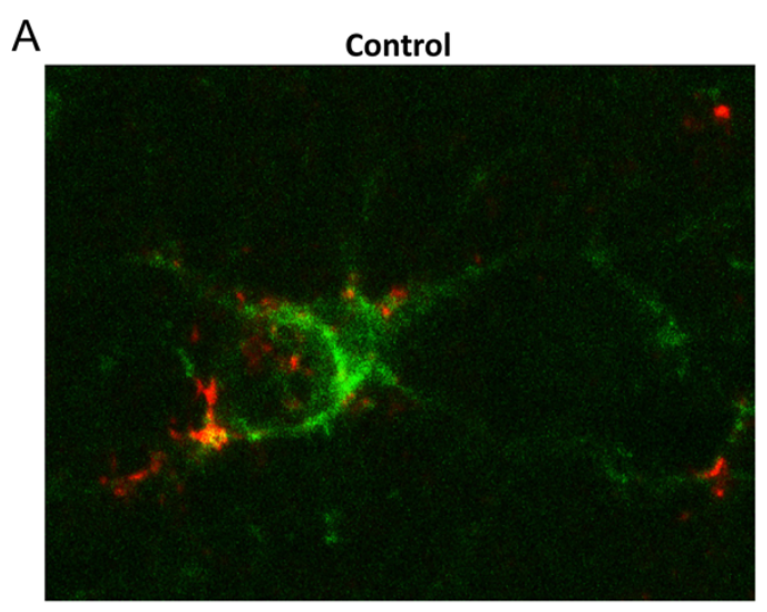

B

FTLD-U

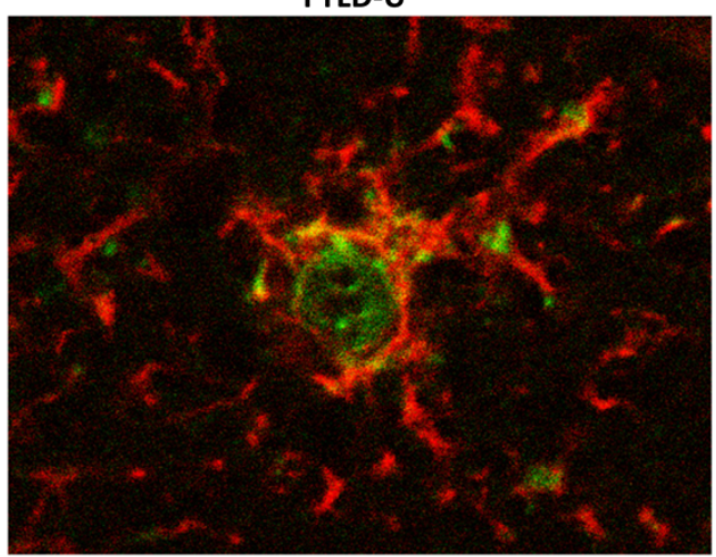

C

Control

$\mathrm{D}$

FTLD-U
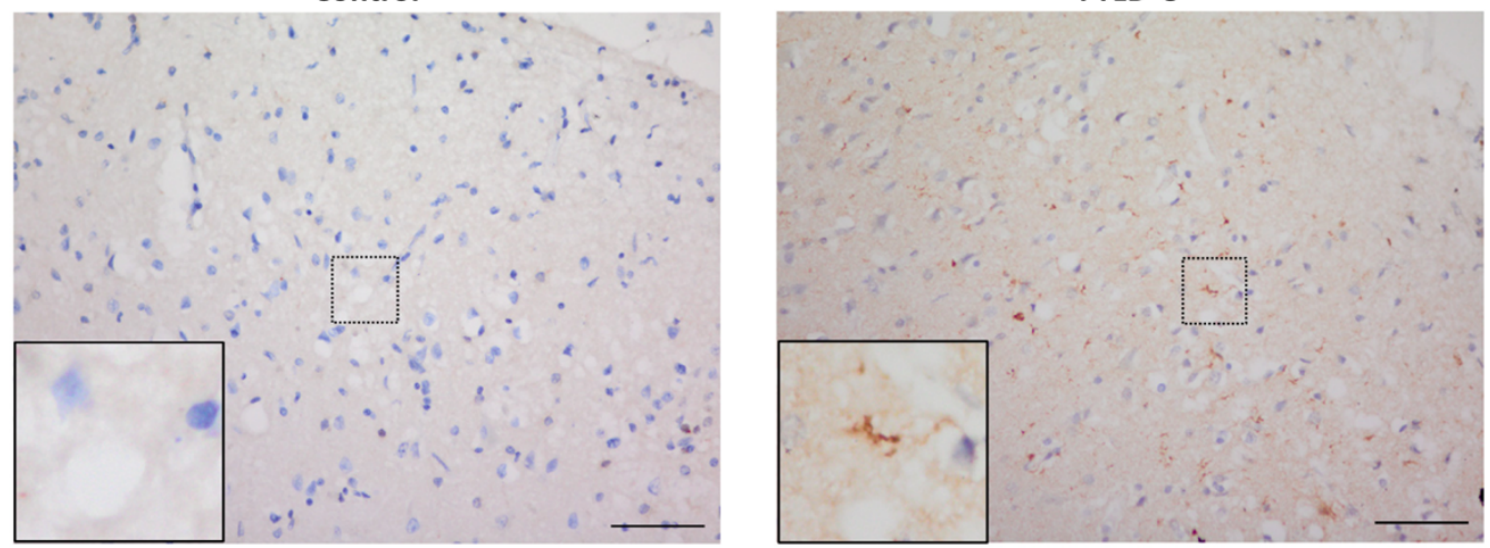

E

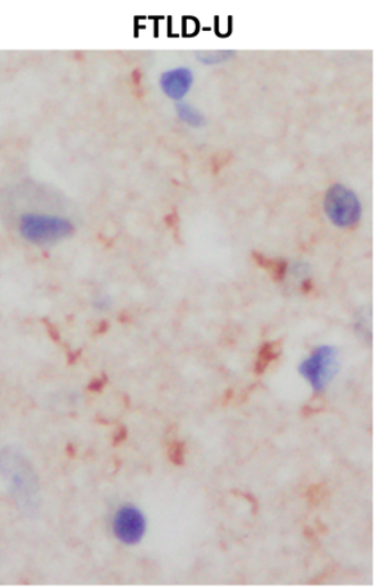

F

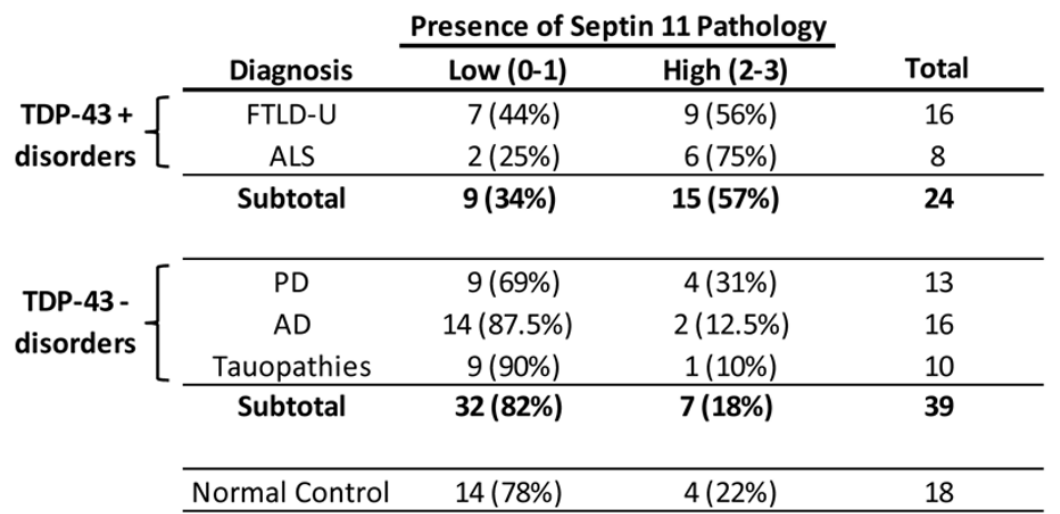

Figure 4 SEPT11 immunoreactivity in control and FTLD-U using polyclonal N-terminal antibody. (a-b) Double label immunofluorescence in control (a) and FTLD-U (b) frontal cortex reveals overlap between SEPT11 (red) and glial fibrillary acidic protein (GFAP; green), suggesting that cell-associated staining localizes to astrocyte cell bodies and processes. (c-e) IHC in FTLD-U (d and e) frontal cortex detects both linear and rounded accumulations of SEPT11 that are absent in control (c). Unlike in (a) and (b), these SEPT11 threads were not associated with specific cell bodies. (f) Summary of blinded scoring of frontal cortex from 81 cases and controls for the presence of SEPT11 threads. 
proteomics-based strategy incorporated pooled samples of FTLD-U and control cases to reduce the impact of biological variability that is unavoidable and uncontrollable in studies of human autopsy materials. Factors, such as postmortem interval, unknown agonal circumstances, and other individual features unique to every patient, introduce enormous noise in efforts to identify diseasespecific elements. Although accepted criteria for FTLD$\mathrm{U}$ have been established, our understanding of this neuropathological entity is far from complete. This is clearly demonstrated by ongoing efforts to subclassify FTLD-U cases based on specific features of TDP-43 immunoreactivity. We have now shown that pathological accumulation of SEPT11 in superficial cortical layers defines an additional molecular feature linked to FTLD-U, and closer examination of candidates identified through proteomic profiling will reveal additional features that will produce a clearer understanding of this complex neurodegenerative disorder.

\section{Methods}

\section{Case Material}

Post-mortem human brain tissues corresponding to diagnoses of FTLD-U, AD, PD, ALS, tauopathy, and unaffected control were obtained from the Alzheimer's Disease Research Center (ADRC) and Center for Neurodegenerative Disease (CND) Brain Bank at Emory University School of Medicine. Diagnoses of FTLD-U, AD, and control cases were made in accordance with established criteria as described previously [41,42]. Diagnoses of PD/Lewy Body Dementia [43], ALS [44], and tauopathy [45-47] were also made based on established criteria.

\section{Antibodies}

In-house SEPT11 antibody (rabbit polyclonal) was raised against keyhole limpet hemocyanin (KLH)-conjugated peptide AVAVGRPSNEELRN at the extreme $\mathrm{N}$-terminus of the protein. Serum from the immunized rabbit was tested by immunoblot and affinity-purified on a column using the immunizing peptide. Commercially available primary antibodies used in these studies were septin 11 (N-15; Santa Cruz Biotechnology, Santa Cruz CA) and glial fibrillary acidic protein (DAKO, Carpinteria CA).

\section{DNA Constructs}

The full-length SEPT11 coding sequence (nucleotides 11287, encoding amino acids 1-429) was amplified by PCR from a commercial expression plasmid (Origene, Rockville MD; Clone ID TC113610) using forward primer 5'-AGCTGCGTCTAGAATGGCCGTGGCCGT GGG-3' and reverse primer 5'-ATACGATATTTCTAGAACTGCAAAAGCAGGTGAATG-3'. The PCR products were digested and cloned into the pcDNA3.1-HA expression vector downstream of the two-HA motifs (peptide YPYDVDYA). The N-terminal HA expression vectors were confirmed by DNA sequencing (Agencourt Bioscience Corporation, Beverly MA).

\section{Sequential Biochemical Fractionation}

Sequential extractions were performed as previously described [23] with buffers containing $1 \%$ Triton X-100, $1 \% \mathrm{~N}$-Lauroyl-sarcosine (sarkosyl), and finally $7 \mathrm{M}$ urea/ $2 \mathrm{M}$ thiourea. Generally, the protein yield in urea samples during sequential extraction was approximately $2 \%$ of the starting material.

\section{Protein Identification and Quantification by LC-MS/MS}

XIC-based label-free quantitative proteomics on pooled urea-soluble fractions was performed as previously described [23]. For quantitative proteomics with CDIT, HEK293 cells were cultured in DMEM (deficient in LLysine and L-Arginine) supplemented with $2 \%$ dialyzed fetal calf serum (Invitrogen) as described [48]. For stable isotopic labeling, heavy forms L-Arginine and L-Lysine were added (Arg10/Lys8, Cambridge Isotope Laboratories) to a final concentration of $0.13 \mathrm{mM}$. Excess proline was added at $200 \mathrm{mg} / \mathrm{L}$ to block the conversion of arginine to proline. Prior to SDS PAGE, $10 \mu \mathrm{g}$ of heavy labeled HEK whole cell lysate was added to $10 \mu \mathrm{g}$ of unlabeled urea fraction from 4 pooled FTLD-U or control cases. The mixed (light and heavy) samples were reduced with $10 \mathrm{mM}$ DTT, and resolved on a $10 \%$ polyacrylamide SDS gel. After staining with Coomassie blue, each gel lane was cut into five gel bands, and bands were subjected to in-gel digestion $(12.5 \mu \mathrm{g} / \mathrm{ml}$ trypsin). Extracted peptides were analyzed via LC-MS/MS as described previously [23]. To compare medium and heavy labeled samples, database searches were modified to include static modifications of +4.02511 on Lys and +6.02013 on Arg, and dynamic modifications of +3.98909 on Lys and +3.98814 on Arg to account for mass difference between medium and heavy labeled peptides. Quantitative pair-wise comparisons between FTLD-U and control using the internal standard were carried out as described previously [21,31,49].

\section{Quantitative analysis of SEPT11 by targeted proteomics}

For targeted proteomics and peptide mapping of SEPT11, metabolically heavy-labeled HEK 293 cells were transfected with tagged HA-SEPT11 constructs and harvested. The cell lysate alone (for peptide mapping) or mixed with urea extracts from 4 pooled FTLD-U cases was analyzed by LC-MS/MS in a data-independent MS/ MS mode to specifically identify and fragment ions corresponding to five pre-selected SEPT11 peptides (Additional File 6). Quantitative analysis was performed with non-transfected heavy-labeled HEK 293 cell lysate as internal standards. The labeled cells were spiked into 
detergent-insoluble fractions from 4 pooled FTLD-U and 4 pooled control cases. Samples were then resolved by SDS-PAGE, and the gel piece corresponding to 40-60 $\mathrm{kDa}$ in each sample was subjected to trypsin in-gel digestion. We then specifically quantified MS/MS ion pairs for SEPT11 peptides AAAQLLQSQAQQSGAQQTK and FESDPATHNEPGVR.

\section{Immunohistochemistry}

Paraffin-embedded sections of hippocampus and frontal cortex (8 $\mu \mathrm{m}$ thick) were deparaffinized and microwaved in citrate buffer $(0.01 \mathrm{M}, \mathrm{pH}$ 6) for 10 minutes. After cooling to room temperature for 1 hour, sections were rinsed and endogenous peroxidase activity was blocked with $3 \%$ hydrogen peroxide at $40^{\circ} \mathrm{C}$. Sections were then incubated with normal goat serum for 15 minutes at $40^{\circ}$ $\mathrm{C}$, followed by primary antibody (diluted in 1\% BSA) overnight at $4{ }^{\circ} \mathrm{C}$. The following day, sections were incubated with biotinylated goat secondary antibody for 30 minutes at $37^{\circ} \mathrm{C}$, and finally with avidin-biotin peroxidase complex (Vector Laboratories) for 60 minutes at $37^{\circ} \mathrm{C}$. 3,3'-Diaminobenzidine (DAB) was used as the chromogen for color development and was followed with hematoxylin counterstain.

\section{Scoring of SEPT11 Immunoreactivity}

Scoring of specific SEPT11 immunoreactivity in paraffin-embedded sections of frontal cortex was done in a blinded fashion by three independent raters. Scoring was limited to superficial cortical layers (layers 2-3) and included only thread-like structures not directly associated with glial nuclei or processes. Astrocytic SEPT11staining was specifically excluded and was, therefore, not evaluated. Staining was scored as negative ( 0 ; no immunoreactivity), equivocal (1; very few threads), positive (2; threads common throughout superficial layers or showing patchy dense distribution), or very positive (3; threads densely distributed throughout superficial layers). A consensus score was determined for each of the cases examined, and typically corresponded to the median score of the three scorers. In rare cases where the three scorers differed by more than 1 point, cases were re-evaluated in the presence of all three scorers. In analyses, samples scored as negative or equivocal were grouped together as "Low Presence of SEPT11 Threads," while samples scored as positive or very positive were grouped together as "High Presence of SEPT11 Threads." We considered age of onset, age at death, post-mortem interval, disease duration, tissue quality, and tissue volume as potential confounders for statistical analyses. However, none of these parameters was significantly associated with predicting the presence or absence of SEPT11 threads. Thus, statistical comparisons were conducted using Fisher's exact test.

\section{Western Blotting}

Immunoblotting was performed according to standard procedures as described previously [49]. Notably, acquired data were analyzed with GraphPad Prism 4.0 software (La Jolla, CA) and statistical significance was determined by unpaired two-tailed Student's t test with $\alpha=0.05$. For preabsorption studies of SEPT11, primary antibodies were preincubated with $100 \times$ molar excess of the antigen overnight at $4^{\circ} \mathrm{C}$ before incubation with the blot.

\section{Additional material}

Additional file 1: Separation of pooled urea samples by SDS-PAGE for proteomic analysis. (a) SDS-PAGE gel of urea fractions extracted from AD, FTLD- $U$, and control pooled frontal cortex homogenates (10 cases each). (b) SDS-PAGE gel of 4 pooled FTLD-U or 4 pooled control samples after addition of heavy labeled cell lysate. The gels were stained with Coomassie Blue G-250 and gel lanes were excised in 5 pieces as indicated (F1-F5 or C1-C5).

Additional file 2: Statistical evaluation and filtering of label-free proteomics data. (a) Abundance ratios for FTLD-U/Control comparison were transformed (logarithmic base 2) and plotted with each point corresponding to the number of proteins in 0.3 unit windows (black line). A Gaussian curve was subsequently fitted to the data (red line) and used to determine significance levels for protein change. (b) Fitted normal distributions for all possible pair-wise comparisons. Statistical means, standard deviations, and regression coefficients are presented in Additional File 3.

Additional file 3: Statistical data for fitted normal distributions Table detailing the specific properties of each fitted normal distribution used for proteomic data analysis.

Additional file 4: Statistical evaluation and filtering of CDIT proteomics data. Abundance ratios for FTLD-U/Control comparison were transformed (logarithmic base 2) and plotted with each point corresponding to the number of proteins in 0.4 unit windows (black line). A Gaussian curve was subsequently fitted to the data (red line) and used to determine significance levels for protein change.

Additional file 5: Peptide map of SEPT11. Amino acid sequence of full length SEPT11 (429 aa) marked with peptides identified in shotgun proteomics approaches (solid underline), mapped unique peptides in targeted proteomics (red color), peptides quantified using targeted proteomics (bold), and immunizing peptide used in development of inhouse SEPT11 rabbit polyclonal antibody (dotted underline).

Additional file 6: SEPT11 peptides selected for targeted proteomics Table detailing properties of SEPT11 peptides selected for targeted proteomics.

Additional file 7: Assessment of SEPT11 in detergent-soluble fractions by immunoblotting. Triton X-100 (a) and Sarkosyl (b) fractions extracted from frontal cortex samples of individual FTLD- $U$ and control cases were immunoblotted with an $\mathrm{N}$-terminus specific rabbit polyclonal SEPT11 antibody. While full-length SEPT11 (49 kDa) is abundant in both detergent-soluble fractions, the low molecular weight fragments noted in the urea fractions (Figure 3) were decreased or absent in these fractions. The band noted at $\sim 40 \mathrm{kDa}$ is non-specific as determined by preabsorption studies using the immunizing peptide.

Additional file 8: Individual Case Demographic and Scoring Information. Table detailing specific demographic data and scoring results for all cases analyzed by immunohistochemistry.

List of Abbreviations

FTLD: frontotemporal lobar degeneration; FTLD-U: frontotemporal lobar degeneration with ubiquitinated inclusions; LC-MS/MS: liquid 
chromatography and tandem mass spectrometry; XIC: extracted ion current; CDIT: culture derived isotopic tags.

\section{Acknowledgements}

This work was supported by NIH grants P50 AG025688, P30 NS055077, Consortium for Frontotemporal Dementia Research (CFR), and NIH training grants F30 NS057902 to YMG and F32 NS007480 to NTS. The funders had no role in study design, data collection and analysis, decision to publish, or preparation of the manuscript.

\section{Author details}

${ }^{1}$ Department of Neurology, Emory University School of Medicine, Atlanta, GA 30322. USA. ²Department of Human Genetics, Emory University School of Medicine, Atlanta, GA 30322. USA. ${ }^{3}$ Emory Proteomics Service Center, Emory University School of Medicine, Atlanta, GA 30322. USA. ${ }^{4}$ Center for Neurodegenerative Diseases, Alzheimer's Disease Research Center, Emory University School of Medicine, Atlanta, GA 30322. USA.

\section{Authors' contributions}

YMG, JP, AlL, and JJL conceived and designed the overall study with help from NTS (proteomics), QX (proteomics), MG (pathology), JDG (pathology), JW (pathology), JJF (DNA constructs), and CJH (immunoassays). YMG, NTS, DMD, DC, QX, and JP performed the proteomics studies. YMG, MG, JDG, HDR, JJF, DSC, AlL, and JJL performed the IHC and immunoblotting experiments. YMG, CJH, AlL, and JJL designed, developed, and characterized the SEPT11-specific antibody. JW carried out statistical analyses in immunohistochemical studies. YMG drafted the manuscript with help from all co-authors. JP, AIL, and $J \mathrm{~J}$ coordinated the study and finalized the manuscript. All authors read and approved the final manuscript.

\section{Competing interests}

The authors declare that they have no competing interests.

Received: 15 June 2011 Accepted: 29 November 2011 Published: 29 November 2011

\section{References}

1. Neary D, Snowden J, Mann D: Frontotemporal dementia. Lancet Neurol 2005, 4:771-780.

2. Neary D, Snowden JS, Mann DM: Classification and description of frontotemporal dementias. Ann N Y Acad Sci 2000, 920:46-51.

3. Okamoto K, Hirai S, Yamazaki T, Sun XY, Nakazato Y: New ubiquitinpositive intraneuronal inclusions in the extra-motor cortices in patients with amyotrophic lateral sclerosis. Neurosci Lett 1991, 129:233-236.

4. Baker M, Mackenzie IR, Pickering-Brown SM, Gass J, Rademakers R, Lindholm C, Snowden J, Adamson J, Sadovnick AD, Rollinson S, Cannon A, Dwosh E, Neary D, Melquist S, Richardson A, Dickson D, Berger Z, Eriksen J, Robinson T, Zehr C, Dickey CA, Crook R, McGowan E, Mann D, Boeve B, Feldman $\mathrm{H}$, Hutton M: Mutations in progranulin cause tau-negative frontotemporal dementia linked to chromosome 17. Nature 2006, 442:916-919.

5. Cruts M, Gijselinck I, van der Zee J, Engelborghs S, Wils H, Pirici D, Rademakers R, Vandenberghe R, Dermaut B, Martin JJ, van Duijn C, Peeters K, Sciot R, Santens P, De Pooter T, Mattheijssens M, Van den Broeck M, Cuijt I, Vennekens K, De Deyn PP, Kumar-Singh S, Van Broeckhoven C: Null mutations in progranulin cause ubiquitin-positive frontotemporal dementia linked to chromosome 17q21. Nature 2006, 442:920-924.

6. Neumann M, Sampathu DM, Kwong LK, Truax AC, Micsenyi MC, Chou TT, Bruce J, Schuck T, Grossman M, Clark CM, McCluskey LF, Miller BL, Masliah E, Mackenzie IR, Feldman H, Feiden W, Kretzschmar HA, Trojanowski JQ, Lee VM: Ubiquitinated TDP-43 in frontotemporal lobar degeneration and amyotrophic lateral sclerosis. Science 2006, 314:130-133.

7. Gitcho MA, Baloh RH, Chakraverty S, Mayo K, Norton JB, Levitch D, Hatanpaa KJ, White CL, Bigio EH, Caselli R, Baker M, Al-Lozi MT, Morris JC, Pestronk A, Rademakers R, Goate AM, Cairns NJ: TDP-43 A315T mutation in familial motor neuron disease. Ann Neurol 2008, 63:535-538.

8. Sreedharan J, Blair IP, Tripathi VB, Hu X, Vance C, Rogelj B, Ackerley S, Durnall JC, Williams KL, Buratti E, Baralle F, de Belleroche J, Mitchell JD, Leigh PN, Al-Chalabi A, Miller CC, Nicholson G, Shaw CE: TDP-43 mutations in familial and sporadic amyotrophic lateral sclerosis. Science 2008, 319:1668-1672.

9. Kabashi E, Valdmanis PN, Dion P, Spiegelman D, McConkey BJ, Vande Velde C, Bouchard JP, Lacomblez L, Pochigaeva K, Salachas F, Pradat PF, Camu W, Meininger V, Dupre N, Rouleau GA: TARDBP mutations in individuals with sporadic and familial amyotrophic lateral sclerosis. Nat Genet 2008, 40:572-574.

10. Rutherford NJ, Zhang YJ, Baker M, Gass JM, Finch NA, Xu YF, Stewart H, Kelley BJ, Kuntz K, Crook RJ, Sreedharan J, Vance C, Sorenson E, Lippa C, Bigio EH, Geschwind DH, Knopman DS, Mitsumoto H, Petersen RC, Cashman NR, Hutton M, Shaw CE, Boylan KB, Boeve B, Graff-Radford NR, Wszolek ZK, Caselli RJ, Dickson DW, Mackenzie IR, Petrucelli L, Rademakers R: Novel mutations in TARDBP (TDP-43) in patients with familial amyotrophic lateral sclerosis. PLoS Genet 2008, 4:e1000193.

11. Zhang YJ, Xu YF, Dickey CA, Buratti E, Baralle F, Bailey R, Pickering-Brown S, Dickson D, Petrucelli L: Progranulin mediates caspase-dependent cleavage of TAR DNA binding protein-43. J Neurosci 2007, 27:10530-10534.

12. Johnson BS, McCaffery JM, Lindquist S, Gitler AD: A yeast TDP-43 proteinopathy model: Exploring the molecular determinants of TDP-43 aggregation and cellular toxicity. Proc Natl Acad Sci USA 2008, 105:6439-6444

13. Polymenidou M, Lagier-Tourenne C, Hutt KR, Huelga SC, Moran J, Liang TY, Ling SC, Sun E, Wancewicz E, Mazur C, Kordasiewicz H, Sedaghat Y, Donohue JP, Shiue L, Bennett CF, Yeo GW, Cleveland DW: Long pre-mRNA depletion and RNA missplicing contribute to neuronal vulnerability from loss of TDP-43. Nat Neurosci 2011, 14:459-468.

14. Geser F, Martinez-Lage M, Kwong LK, Lee VM, Trojanowski JQ: Amyotrophic lateral sclerosis, frontotemporal dementia and beyond: the TDP-43 diseases. J Neurol 2009.

15. Lagier-Tourenne C, Polymenidou M, Cleveland DW: TDP-43 and FUS/TLS: emerging roles in RNA processing and neurodegeneration. Hum $\mathrm{Mol}$ Genet 2010, 19:R46-64.

16. Sampathu DM, Neumann M, Kwong LK, Chou TT, Micsenyi M, Truax A, Bruce J, Grossman M, Trojanowski JQ, Lee VM: Pathological heterogeneity of frontotemporal lobar degeneration with ubiquitin-positive inclusions delineated by ubiquitin immunohistochemistry and novel monoclonal antibodies. Am J Pathol 2006, 169:1343-1352.

17. Mackenzie IR, Baborie A, Pickering-Brown S, Du Plessis D, Jaros E, Perry RH, Neary D, Snowden JS, Mann DM: Heterogeneity of ubiquitin pathology in frontotemporal lobar degeneration: classification and relation to clinical phenotype. Acta Neuropathol 2006, 112:539-549.

18. Cairns NJ, Bigio EH, Mackenzie IR, Neumann M, Lee VM, Hatanpaa KJ, White CL, Schneider JA, Grinberg LT, Halliday G, Duyckaerts C, Lowe JS, Holm IE, Tolnay M, Okamoto K, Yokoo H, Murayama S, Woulfe J, Munoz DG, Dickson DW, Ince PG, Trojanowski JQ, Mann DM: Neuropathologic diagnostic and nosologic criteria for frontotemporal lobar degeneration: consensus of the Consortium for Frontotemporal Lobar Degeneration. Acta Neuropathol 2007, 114:5-22.

19. Neumann M, Rademakers R, Roeber S, Baker M, Kretzschmar HA, Mackenzie IR: A new subtype of frontotemporal lobar degeneration with FUS pathology. Brain 2009, 132:2922-2931.

20. Ishihama Y, Sato T, Tabata T, Miyamoto N, Sagane K, Nagasu T, Oda Y: Quantitative mouse brain proteomics using culture-derived isotope tags as internal standards. Nat Biotechnol 2005, 23:617-621.

21. Cheng D, Hoogenraad CC, Rush J, Ramm E, Schlager MA, Duong DM, Xu P, Wijayawardana SR, Hanfelt J, Nakagawa T, Sheng M, Peng J: Relative and absolute quantification of postsynaptic density proteome isolated from rat forebrain and cerebellum. Mol Cell Proteomics 2006, 5:1158-1170.

22. Nagata $K$, Asano T, Nozawa $Y$, Inagaki M: Biochemical and cell biological analyses of a mammalian septin complex, Sept7/9b/11. J Biol Chem 2004 279:55895-55904.

23. Gozal YM, Duong DM, Gearing M, Cheng D, Hanfelt JJ, Funderburk C, Peng J, Lah JJ, Levey Al: Proteomics analysis reveals novel components in the detergent-insoluble subproteome in Alzheimer's disease. J Proteome Res 2009, 8:5069-5079.

24. Hartwell LH: Genetic control of the cell division cycle in yeast. IV. Genes controlling bud emergence and cytokinesis. Exp Cell Res 1971, 69:265-276.

25. Spiliotis ET, Nelson WJ: Here come the septins: novel polymers that coordinate intracellular functions and organization. J Cell Sci 2006, 119:4-10. 
26. Kinoshita M: Assembly of mammalian septins. J Biochem 2003, 134:491-496.

27. Hall PA, Jung K, Hillan KJ, Russell SE: Expression profiling the human septin gene family. J Pathol 2005, 206:269-278.

28. Tada T, Simonetta A, Batterton M, Kinoshita M, Edbauer D, Sheng M: Role of Septin cytoskeleton in spine morphogenesis and dendrite development in neurons. Curr Biol 2007, 17:1752-1758.

29. Kojima K, Sakai I, Hasegawa A, Niiya H, Azuma T, Matsuo Y, Fujii N, Tanimoto M, Fujita S: FLJ10849, a septin family gene, fuses MLL in a novel leukemia cell line CNLBC1 derived from chronic neutrophilic leukemia in transformation with $\mathrm{t}(4 ; 11)(\mathrm{q} 21 ; \mathrm{q} 23)$. Leukemia 2004, 18:998-1005.

30. Rissman RA, Poon WW, Blurton-Jones M, Oddo S, Torp R, Vitek MP, LaFerla FM, Rohn TT, Cotman CW: Caspase-cleavage of tau is an early event in Alzheimer disease tangle pathology. J Clin Invest 2004, 114:121-130.

31. Li X, Serwanski DR, Miralles CP, Nagata K, De Blas AL: Septin 11 is present in GABAergic synapses and plays a functional role in the cytoarchitecture of neurons and GABAergic synaptic connectivity. J Biol Chem 2009, 284:17253-17265.

32. Kinoshita A, Kinoshita M, Akiyama H, Tomimoto H, Akiguchi I, Kumar S, Noda M, Kimura J: Identification of septins in neurofibrillary tangles in Alzheimer's disease. Am J Pathol 1998, 153:1551-1560.

33. Ihara M, Tomimoto H, Kitayama H, Morioka Y, Akiguchi I, Shibasaki H, Noda M, Kinoshita M: Association of the cytoskeletal GTP-binding protein Sept4/H5 with cytoplasmic inclusions found in Parkinson's disease and other synucleinopathies. J Biol Chem 2003, 278:24095-24102.

34. Zhang Y, Gao J, Chung KK, Huang H, Dawson VL, Dawson TM: Parkin functions as an E2-dependent ubiquitin- protein ligase and promotes the degradation of the synaptic vesicle-associated protein, CDCrel-1. Proc Natl Acad Sci USA 2000, 97:13354-13359.

35. Spiliotis ET, Kinoshita M, Nelson WJ: A mitotic septin scaffold required for Mammalian chromosome congression and segregation. Science 2005, 307:1781-1785.

36. Hanai N, Nagata K, Kawajiri A, Shiromizu T, Saitoh N, Hasegawa Y, Murakami S, Inagaki M: Biochemical and cell biological characterization of a mammalian septin, Sept11. FEBS Lett 2004, 568:83-88.

37. Cairns NJ, Lee VM, Trojanowski JQ: The cytoskeleton in neurodegenerative diseases. J Pathol 2004, 204:438-449.

38. Sheffield PJ, Oliver CJ, Kremer BE, Sheng S, Shao Z, Macara IG: Borg/septin interactions and the assembly of mammalian septin heterodimers, trimers, and filaments. J Biol Chem 2003, 278:3483-3488.

39. Ross CA, Poirier MA: Protein aggregation and neurodegenerative disease. Nat Med 2004, 10(Suppl):S10-17.

40. Pesiridis GS, Tripathy K, Tanik S, Trojanowski JQ, Lee VM: A "Two-hit" Hypothesis for Inclusion Formation by Carboxyl-terminal Fragments of TDP-43 Protein Linked to RNA Depletion and Impaired Microtubuledependent Transport. J Biol Chem 2011, 286:18845-18855.

41. Gozal YM, Cheng D, Duong DM, Lah JJ, Levey Al, Peng J: Merger of laser capture microdissection and mass spectrometry: a window into the amyloid plaque proteome. Methods Enzymol 2006, 412:77-93.

42. Gozal YM, Dammer EB, Duong DM, Cheng D, Gearing M, Rees HD, Peng J, Lah JJ, Levey Al: Proteomic analysis of hippocampal dentate granule cells in frontotemporal lobar degeneration: application of laser capture technology. Front Neurol 2011, 2:24.

43. McKeith IG, Dickson DW, Lowe J, Emre M, O'Brien JT, Feldman H, Cummings J, Duda JE, Lippa C, Perry EK, Aarsland D, Arai H, Ballard CG, Boeve B, Burn DJ, Costa D, Del Ser T, Dubois B, Galasko D, Gauthier S, Goetz CG, Gomez-Tortosa E, Halliday G, Hansen LA, Hardy J, Iwatsubo T, Kalaria RN, Kaufer D, Kenny RA, Korczyn A, Kosaka K, Lee VM, Lees A, Litvan I, Londos E, Lopez OL, Minoshima S, Mizuno Y, Molina JA, Mukaetova-Ladinska EB, Pasquier F, Perry RH, Schulz JB, Trojanowski JQ, Yamada M: Diagnosis and management of dementia with Lewy bodies: third report of the DLB Consortium. Neurology 2005, 65:1863-1872.

44. Ince PG, Lowe J, Shaw PJ: Amyotrophic lateral sclerosis: current issues in classification, pathogenesis and molecular pathology. Neuropathol Appl Neurobiol 1998, 24:104-117

45. Dickson DW: Neuropathology of Pick's disease. Neurology 2001, 56:S16-20.

46. Dickson DW, Bergeron C, Chin SS, Duyckaerts C, Horoupian D, Ikeda K, Jellinger K, Lantos PL, Lippa CF, Mirra SS, Tabaton M, Vonsattel JP,
Wakabayashi K, Litvan I: Office of Rare Diseases neuropathologic criteria for corticobasal degeneration. J Neuropathol Exp Neurol 2002, 61:935-946.

47. Hauw JJ, Daniel SE, Dickson D, Horoupian DS, Jellinger K, Lantos PL, McKee A, Tabaton M, Litvan I: Preliminary NINDS neuropathologic criteria for Steele-Richardson-Olszewski syndrome (progressive supranuclear palsy). Neurology 1994, 44:2015-2019.

48. Allison DB, Cui X, Page GP, Sabripour M: Microarray data analysis: from disarray to consolidation and consensus. Nature reviews 2006, 7:55-65.

49. Seyfried NT, Gozal YM, Dammer EB, Xia Q, Duong DM, Cheng D, Lah JJ, Levey Al, Peng J: Multiplex SILAC analysis of a cellular TDP-43 proteinopathy model reveals protein inclusions associated with SUMOylation and diverse polyubiquitin chains. Mol Cell Proteomics 2010 9:705-718.

doi:10.1186/1750-1326-6-82

Cite this article as: Gozal et al:: Aberrant septin 11 is associated with sporadic frontotemporal lobar degeneration. Molecular Neurodegeneration $20116: 82$.

\section{Submit your next manuscript to BioMed Central and take full advantage of:}

- Convenient online submission

- Thorough peer review

- No space constraints or color figure charges

- Immediate publication on acceptance

- Inclusion in PubMed, CAS, Scopus and Google Scholar

- Research which is freely available for redistribution 